\title{
Health outcomes, education, healthcare delivery and quality - 3063. Cost-effectiveness of immunotherapy for children with atopic dermatitis
}

\author{
Vladislava Derkach ${ }^{1}$, Tatiana Slavyanskaya ${ }^{2^{*}}$ \\ From 2nd WAO International Scientific Conference (WISC 2012) \\ Hyderabad, India. 6-9 December 2012
}

\section{Background}

The study was aimed at evaluating the cost-effectiveness of immunotherapy (IT) for children (Ch) with atopic dermatitis (AD).

\section{Methods}

There were examined 94 $\mathrm{Ch}$ aged 3-18 years with AD and duration of disease 1-15 years. Patients underwent the standard general clinical and immunological and allergy survey. The treatment consisted of 2 stages: traditional therapy (TT) for reducing disease complications, and IT. Patients were divided in 3 groups: I group $(n=30)$ received stepped therapy with immune response-modulating agent (IRMA) in course dose of $20 \mathrm{mg}$; II group $(\mathrm{n}=31)$ was treated with parenteral accelerated allergenspecific immunotherapy (APAI); III group $(n=33)$ received combination of IT - CIT (IRMA+APAI) on the fast track scheme. Pharmacoeconomic assessments were performed using cost-effectiveness analysis.

\section{Results}

The cost of a pack of IRMA was \$7.67. The cost of 1 year APAI was \$32.2. After 2 courses of IRMA the TT costs in I group were $\$ 189.69 \pm 1.08$, in II group- $\$ 69.14 \pm 0.93$, and in III group- $\$ 32.34$. Three years of 2 consecutive courses in I group resulted in mean treatment costs of $\$ 569.06$; 3 consecutive courses in II group- in mean treatment costs of $\$ 104.00$, and $\$ 97.01$ in III group for the same period. In addition, CIT provided long-term remission, reduced number of hospitalization, prevented AD progression, improved skin condition of children with AD, thus normalizing emotional balance. Furthermore there was

${ }^{2}$ Allergology \& Immunology, University of Russia, Moscow, Russia Full list of author information is available at the end of the article indirect costs minimization $-2 / 3$ reduction of parents' sick leaves payments.

\section{Conclusions}

The clinico-economic analysis showed that despite the complexity of APAI, CIT method improves the quality of life of children with $\mathrm{AD}$, provides pharmacotherapy and medical services costs reduction, and it is more cost-effective.

\section{Author details \\ ${ }^{1}$ Vladivostok State Medical University, Vladivostok, Russia. ${ }^{2}$ Allergology \& Immunology, University of Russia, Moscow, Russia.}

Published: 23 April 2013

doi:10.1186/1939-4551-6-S1-P228

Cite this article as: Derkach and Slavyanskaya: Health outcomes,

education, healthcare delivery and quality - 3063. Cost-effectiveness of immunotherapy for children with atopic dermatitis. World Allergy Organization Journal 2013 6(Suppl 1):P228.

Submit your next manuscript to BioMed Central and take full advantage of:

- Convenient online submission

- Thorough peer review

- No space constraints or color figure charges

- Immediate publication on acceptance

- Inclusion in PubMed, CAS, Scopus and Google Scholar

- Research which is freely available for redistribution 